\title{
The Paradox of the American War on Poverty
}

\author{
Sunday I. Odezah \\ The University of Oklahoma, Oklahoma, USA
}

\begin{abstract}
Poverty is an old concept that is taking on a new lease and it remains an unsolved global problem. In an effort to solve the problem, the United Nations World Summit for Social Development has declared the eradication of poverty as the unfinished business of the 21 st century. This paper discusses the efforts to eradicate poverty in America. Despite the fact that American government has spent trillions of dollars to solve the poverty problem in America, more than 46 million Americans live in poverty. The reasons for this paradox are explored and explicated in this paper. The paper concludes with suggestions to make the American war on poverty-efforts to eradicate poverty in America - more efficient, effective, and productive. Above all, as former President Ronald Reagan once said, America fought a war on poverty and poverty won. With that in mind, this paper challenges American government head-on to rethink and reconsider how it fights the war on poverty.
\end{abstract}

Keywords: war on poverty, poverty, welfare, great society, New Deal

Poverty is an old concept that is taking on a new lease and it remains a mystery and an unsolved global problem, even to this day. To illustrate, over 3,000 years ago, Moses and Matthew wrote, respectively: “... the poor shall never cease out of the land..." (Deut. 15:11 KJV) and "You will always have the poor among you..." (Matt. 26:11 LBV). These two observations imply that poverty is a mystery for the following reasons. First, the observations indicate that poverty is here to stay and that no matter how hard we try, poverty will forever remain with us. Second, according to the observations, some of us are poor today or one day (only time will tell) will be poor for no fault of our own. Even more, the observations are a mystery because many of the "why" questions about poverty will remain a conundrum. That is, when it comes to the "actual" reason(s) why some people are poor, there will be some unanswered questions.

To make matters worse, the concept of poverty is too slippery and too complicated to be defined in simple, statistical terms and to understand with a snap of a finger. As Burns put it, "Poverty is only an 'intellectual concept' defined by 'artificial statistics"” (Harrington, 1981). Add to this, poverty is multi-faceted and all encompassing, affecting all aspects of life, including the economic, physical, and social. To illustrate, in his book, The Other America: Poverty in the United States, Harrington (1981) sent shockwaves to the world when he said:

... the real explanation of why the poor are where they are is that they made the mistake of being born to the wrong parents, in the wrong section of the country, in the wrong industry, or in the wrong racial or ethnic group.

Along this line, Galbraith (1958) told us that poverty can be classified as "case" poverty or "insular" poverty. According to him, the former arises because some quality of the individual (e.g., bad health) has kept

Corresponding author: Sunday I. Odezah, Doctor of Public Administration (DPA), management consultant, The University of Oklahoma; research fields: public management, leadership, administrative theory, nonprofit leadership and management. 
him/her from participating in the general economic well-being. The latter arises when a comparatively large number of people desire to live near the place of their birth and that place suffers from economic hard times.

To their credit, there is an element of truth in Harrington's and Galbraith's arguments. For example, the author believes that chronic and prolonged health problems can lead to poverty. He also believes that the probability for one to become poor is much higher for people who live in economically depressed areas than it is for those who live in areas with a booming, robust economy. However, he argues that Harrington's argument unfairly put the blame on innocent people. The truth is that people, as Harrington himself would agree, do not choose their parents. Rather, for better or worse, our parents are chosen for us from birth and there is nothing we can do about it. If people were free to choose their parents, there would be no such thing as poverty because everybody would like to be born to a rich parent like Bill and Melinda Gates, but this is unrealistic in the real world.

Furthermore, he does not believe that there is a natural law that says anybody who is born to a poor or wrong (Harrington's word) parent will be poor-the so-called "culture-of-poverty" theory. In other words, he does not believe that everybody who is born to a poor parent and lives in the wrong section of the country and industry is poor or will be poor. In contrast, he believes that with hard work and luck, anybody can rise above poverty. This simply means that poverty, in contrast to Moses', Matthew's, Harrington's, and Galbraith's arguments, is not a curse, especially to those who are burn to poor or wrong parents or to a particular ethnic group. However, he does believe that poverty is a "temporary" thing. Second, he believes also that poverty is present in every society and that it is no respecter of racial, sexual, and parental backgrounds. This means that anybody can become poor at any time for several reasons, including chronic and prolonged health problems.

To further complicate the concept, definition, and meaning of poverty, policy makers use a monetary threshold called "poverty line" to determine who is poor and who is not. As used in the United States, a person is automatically considered poor when his/her income falls below the poverty line. Although the poverty line is simple to construct and politically expedient in making policy decisions, it raises more questions than it answers. To illustrate, the poverty line is a pre-determined, arbitrary cut-off point for determining who is poor and who is not poor. As such, the poverty line is an unrealistic and incomplete measure of income and a misleading indicator of who is actually poor, because it does not take into account all the sources of income. For example, as Rector and Sheffield (2014) noted, "The Census Bureau counts a family as 'poor' if its income falls below specific thresholds, but in counting 'income', the Census omits nearly all of government means-tested spending on the poor". In effect, said the authors, the Census "ignores almost the entire welfare state when it calculates poverty".

Finally and further complicating the concept of poverty, there is no generally and universally accepted definition and causes of poverty. Nevertheless, there is general consensus among governments, nations, and world leaders that poverty is pervasive and that it remains an unsolved global problem. With this understanding, the "Eradication of poverty has been declared by the United Nations World Summit for Social Development in 1995 as the unfinished business of the 21st century" (Oladeji, n.d.). The pervasiveness of this problem and efforts to resolve it are summed up in the following quotation from the 1995 World Summit for Social Development: "We are witnessing in countries throughout the world the expansion of prosperity for some, unfortunately accompanied by an expansion of unspeakable poverty for others. This glaring contradiction is unacceptable and needs to be corrected through urgent actions" (United Nations World Summit for Social 
Development, 1995). With that in mind, this paper discusses the efforts to solve the poverty problem in America. To this end, the rest of the paper proceeds as follows:

The first section discusses some (in symbolic terms) of the efforts to solve the poverty problem in America, even before the issuance of the 1995 World Summit for Social Development mandate. The second section delves into some, but not all, of the reasons that the author believes led to the failure of the efforts to solve the poverty problem in America. The third section summarizes the discussion in the preceding two sections in the context of the question: If the war on poverty was supposed to change the lives of poor Americans for the better, how come it has not been able to achieve this noble goal despite the trillions of dollars that have been invested in it? Stated differently, what prevents the American war on poverty from realizing its great promise despite the good intension behind it and despite the trillions of dollars that have been invested in it? The final section draws the paper to a conclusion and offers some suggestions for government policy makers to consider in making better and results-oriented policies to make the American war on poverty more efficient, effective, and productive.

\section{Efforts to Solve the Poverty Problem in America}

Although a major focus of this paper is on President Lyndon B. Johnson's war on poverty, efforts to combat poverty in America pre-date Johnson's administration. As Aaron (1978) noted, "None of the ideas embodied in the Great Society or the War on Poverty was really new. All had been foreshadowed in the New Deal or Fair Deal...”. With that in mind, a brief description of the New Deal as a precursor of President Johnson's war on poverty follows. As a footnote, however, for the purpose of this paper, the wide gap among the New Deal, the war on poverty, and current efforts to solve the poverty problem in America is considered insignificant.

\section{The New Deal: President Franklin D. Roosevelt's Administration (1933-1945)}

In the summer of 1932, Franklin D. Roosevelt was nominated as the presidential candidate of the Democratic Party. At that time, the United States was experiencing the worst economic crisis in its history (The Great Depression of the 1930s). In his acceptance speech, Roosevelt (1932) addressed the problems of the depression by telling the American people: "I pledge you, I pledge myself, to a new deal for the American people". Roosevelt's response to the Great Depression, after taking the oath of office to become the 32th President of the United States in 1933, "was to initiate the 'New Deal'-a series of economic measures designed to alleviate the worst effects of the depression, reinvigorate the economy, and restore the confidence of the American people in their banks and other key institutions" (The New Deal, n.d.). The New Deal programs focused on "3Rs": Relief, Recovery, and Reform. Relief aimed to temporarily help the millions of suffering and unemployed Americans. Recovery strived to help the economy rise up from the depression. Reforms analyzed what caused the depression and attempted to prevent such a crisis from recurring in the future (The New Deal \& 3R'S-Relief, Recovery, Reform, n.d.).

During his tenure in office, Roosevelt passed several pieces of legislation to stabilize the economy and to provide jobs and relief to those who were suffering from the effects of the depression. Some of the most significant and most famous measures of President Roosevelt's New Deal were the Banking Act of 1933, which brought an end to the panic that crippled the nation's banking system; the Works Progress Administration, which provided temporary jobs for the unemployed people instead of placing them on welfare 
roll; and the 1935 Social Security Act, which created a national system of old-age pensions and unemployment compensation. Further, the Act provided federal assistance to the elderly, support for unemployed insurance to prevent hardship in future economic downturns, and Aid to Families with Dependent Children (formerly Aid to Dependent Children) (The New Deal, n.d.; Sribnick, 2014).

Although President Roosevelt's New Deal did not solve the poverty problem in America, it offered hope and restored the faith of the American people in their respective institutions, restored the confidence and spirit of the American people as the president worked to lift the economy out of the Great Depression and laid the groundwork for the federal government to play a key role in the economic and social affairs of poor or less affluent Americans (The New Deal, n.d.). A discussion of Johnson's war on poverty—an off-shoot of the New Deal-follows.

\section{The War on Poverty: President Lyndon Johnson's Administration (1963-1969)}

As noted earlier, the war on poverty is an extension of the New Deal that is carried forward from President Franklin D. Roosevelt's administration. Nevertheless, President Johnson is generally credited for the origin and popularity of the war on poverty. For example, in his January 8, 1964 State of the Union address, Johnson proclaimed, "This administration today, here and now, declares unconditional war on poverty in America" (Johnson, 1964a). He went on to say: "Our aim is not only to relieve the symptom of poverty, but to cure it and, above all, to prevent it". In addition, in his March 1964 Special Message to Congress, Johnson declared that his war would strike "at the causes, not just the consequences of poverty" (Johnson, 1964b). According to Rector (2014),

When Johnson launched the war on poverty, he wanted to give the poor a "hand up, not a hand out". He stated that his war would shrink welfare rolls and turn the poor from "tax-eaters" into "taxpayers". Johnson's aim was to make poor families self-sufficient, able to rise above poverty through their own earnings without dependence on welfare.

Ironically, however, despite all the good intentions behind President Johnson's efforts to "wipe out" poverty in America and to give poor Americans visions of a better world, the war on poverty is often branded a failure and a catastrophe. Maybe so, but as a caring president, Johnson faithfully did all he could to rescue poor Americans from the afflictions and sufferings of poverty and destitution.

\section{The War on Poverty: President Barack Obama's Administration (2009-Present)}

Although the American war on poverty gained popularity during the administration of President Johnson, efforts to combat and eliminate poverty in America did not start and end with Johnson's administration. In other words, as long as we continue to have poor people in America, the war on poverty will remain an unfinished business in America and every American president, now and in the future, has a moral responsibility and obligation to deal with the problem. That said, in terms of cash outlays, President Obama's administration has spent an alarming amount of money to fight the war on poverty in America. According to Tanner (2012), since President Obama took office, federal welfare spending has increased by $41 \%$, more than $\$ 193$ billion per year. While President Obama's spending on welfare is unprecedented, the question is, is it worth it? As will be discussed later, the answer to this question is "yes" and "no".

\section{The Paradox, Puzzle, and Mystery in the American War on Poverty}

Ceteris Paribus (all other things being equal), one would expect the American war on poverty with so 
many trillions of dollars invested in it to have a positive and significant impact on poor Americans. Paradoxically, this has not been the case. According to Tanner (2012), despite the government largess under President Obama, "More than 46 million Americans continue to live in poverty". Similarly, Rector (2014) noted that since President Lyndon Johnson declared unconditional war on poverty in America, the taxpayers have spent $\$ 22$ trillion on the war. Rector noted also that an annual poverty report released by the U.S. Census Bureau claims that in 2013, 14.5\% of Americans were poor. Remarkably, Rector exclaimed, "That's almost the same poverty rate as in 1967, three years after the War on Poverty started". Twenty-three years ago, former Vice President Al Gore (1993) lamented when he said: "We spend \$25 billion a year on welfare, \$27 billion on food stamps, and $\$ 13$ billion on public housing - yet more Americans fall into poverty every year. It is almost as if federal programs were designed not to work". These disappointing results are the paradox or mystery of the American war on poverty. What accounts for this sad and undesirable situation and how can it be explained and resolved? These questions are addressed next.

\section{Probable Reasons for the Failure of the American War on Poverty}

Although it is difficult to tell precisely what "actually" went wrong with the American war on poverty, the author believes that the issues addressed below contributed, directly or indirectly and in whole or in part, to the failure of the war on poverty. These include goal displacement, faulty intervention theory, poor program design, goal ambiguity, unrealistic expectations, and finally, implementation problem. A brief discussion of these issues and how they might have contributed, one way or another, to the failure of the American war on poverty follows.

\section{Goal Displacement}

As used in this paper, goal displacement means losing sight of or being deflected from the original goal(s). This problem is quite evident in the American war on poverty. To illustrate, in his 1964 State of the Union address, President Johnson laid out the goals of his war on poverty, principal among which are: (1) "to give our fellow citizens a fair chance to develop their own capacities"; (2) "our aim is not only to relieve the symptom of poverty, but to cure it and, above all, to prevent it"; and (3) to strike "at the causes, not just the consequences of poverty" (Johnson, 1964b). Unfortunately, however, as laudable as these goals are, the war on poverty is deemed a failure and a catastrophe for "goal displacement" reasons as illustrated below.

After carefully reviewing the literature on the American war on poverty, the author takes the position that the failure of the war on poverty is due in large part to the welfare system itself. Here are the facts. First, instead of giving poor Americans a fair chance to develop their own capacities as Johnson promised, the welfare system weakened the capacity for self-sufficiency, increased welfare dependence, and reduced work incentives by paying welfare recipients more not to work than they can earn at a job and to make more babies at home as a condition for receiving more welfare benefits. Second, although Johnson's aim was to give the poor an opportunity to rise above poverty through their own earnings without dependence on Uncle Sam, the exact opposite happened. That is, instead of giving the poor the tools they need to rise above poverty (e.g., education, training, and jobs), many poor Americans do not have a job and the ever-expanding welfare state and the massive ever-increasing welfare benefits have made the welfare system a booming industry, a safety net for welfare recipients and a political issue for policy-makers on both sides of the political spectrum. 


\section{Faulty Intervention Theory}

By definition and as used in this paper, intervention theories (or program theories) are the presuppositions concerning what the intervention (a program) was designed to achieve and how the achievement was to come about or the reasoning undergirding the program (Vedung, 1997). How does this theory apply to the failure of the war on poverty? Answer! Although the war on poverty was planned and executed with all the good intentions, it, nevertheless, failed or deemed a failure by most people because it was based on faulty presuppositions for the following reasons.

First and foremost, the reasons underlying the declaration of the war on poverty were oversold. According to Aaron (1978),

The first, justly criticized and much ridiculed, is the flamboyant rhetoric in which the declaration of (the) war on poverty was couched. By making his objective "total victory" while refusing to rely primarily on cash transfers, President Johnson made failure inevitable. By assuring Congress that investments in the poor would yield returns "manifold" greater than their costs, Johnson embraced a faith widely shared at the time..., but he was stating targets in such a way that they could not be over fulfilled.

Second, President Johnson declared that the war on poverty would strike "at the causes, not just the consequences of poverty". He also said that his aim is not only to relieve the symptom of poverty, but to cure it and, above all, to prevent it. The truth is, in actuality the problem of poverty is too complicated to be solved with a bleak of an eye. As a matter of fact, many of the "causes" of poverty are a conundrum with no clear-cut explanations and solutions.

Third, with respect to Johnson's goal of promoting self-sufficiency, the exact opposite happened - self-sufficiency turned to dependence on welfare. Tanner (2013) put it very well when he said: "Poor people aren't stupid. If they can get more from the government than they can from a job, many aren't going to work". That said, we need policies to change this attitude in America.

\section{Poor Program Design}

Closely related to faulty intervention theory is the concept of poor program design. Common-sense and experience dictate that it is always a good idea to design a program "right" from the onset or to get it "right" the first time. The rationale is that the manner in which a program is designed determines to a large extent how successfully and effectively it will be implemented. In other words, implementation is not a failure if a program is poorly designed or not feasible in the first place (J. Denhardt \& R. Denhardt, 2007). Despite this simple principle, there are, according to Ripley and Franklin (1986), programs (e.g., American anti-poverty programs) whose design is so poor or whose goals are so far beyond the capacity of anyone to achieve them that not even the most intelligent and conscientious implementation decisions will be able to produce the desired impact. In designing a program, two inter-related questions need to be addressed. Whether the program is designed in conformity with the intended goals and whether there is a coherent rationale underlying the program (Rossi \& Freeman, 1982).

With regard to the war on poverty, examples of poor program design abound. To illustrate, according to Tanner (2012), "The vast majority of current programs are focused on making poverty more comfortable — giving poor people more food, better shelter, health care, and so forth - rather than giving people the tools that will help them escape poverty". Let us get this clear. The author believes that Tanner is not saying that poor people 
should not receive welfare benefits. Rather, he believes that what Tanner is saying is that giving poor people welfare checks indefinitely without a time limit to leave the welfare system is counter-productive, because they will continue to depend on the system for the rest of their lives and refuse to work for their daily bread. Ultimately, this will create dependency and "moral hazard" problems for the poor which will make them worse of.

\section{Goal Ambiguity}

With respect to government programs, goal ambiguity is not a new name in town because every government program contains, to some extent, ambiguous, vague, fuzzy, unclear, and sometimes contradictory goals. The following incisive quotations will make this point clear.

Goals embedded in programs are diffuse, numerous, and usually fuzzy. There is virtually never a single, clear goal on which all parties agree. At best there are many—not always consistent-goals that, in a sense, compete... In some cases there may be goals that are flatly contradictory tied to the same program. (Ripley \& Franklin, 1986, p. 22)

Diffuse, multiple, and competing goal statements are the normal condition, a deliberate product of the conflict, compromise, and negotiation that characterize the formulation and legitimation processes necessary to produce legislation. Goals are vague in order to accommodate multiple points of view... (Ripley \& Franklin, 1986, p. 29)

Question! Do ambiguous, vague and fuzzy goals always mean that policy makers don't know what they are doing? The answer is "yes" or "no." To illustrate, government programs may be deliberately created with ambiguous goals for a number of reasons. For example, as Ripley and Franklin have stated, goals are vague in order to accommodate multiple points of view. (Milakovich \& Gordon, 2004; Lindblom, 1959; Wildavsky, 1979; Jung, 2014)

Second, ambiguous goals are also used to promote and justify a program. As a case in point, Woodrow Wilson, the Founder of the American Public Administration program, used the distinction (later called dichotomy) between politics and administration to promote and justify the establishment of the public administration program in the United States. Even though in practice the dichotomy is both unrealistic and untenable, Wilson, nevertheless, used it effectively to establish public administration as a field of study in the United States because at the time (1887) he wrote the article; the United States needed or was in search of a theory of administration. As Henry (1995) pointed out, "Wilson unquestionably posited one unambiguous thesis in his article that has had a lasting impact on the field: Public administration was worth studying. Political scientists would later create the first identifiable paradigm of public administration around Wilson's contention". As Wilson himself put it in his 1887 article (reprinted in 1941), The Study of Administration, "It is getting to be harder to run a constitution than to frame one", and called for a "science of administration which shall seek to straighten the paths of government..." (Wilson, 1941).

On the "no" side, goals may not be intentionally and deliberately designed to be ambiguous, vague, and fuzzy just to accommodate multiple points of view or to justify the establishment of a program. The truth is, in most cases, decision makers make decisions in an environment filled with uncertainty. In such a situation, they are forced to make decisions within the framework of "bounded rationality" (Simon, 1947; Thompson, 1967; Forester, 1984). In its simplest form, bounded rationality means that the reasoning faculty (or decision-making abilities) of human beings is bounded or limited. Hence decision makers, according to Simon, always "satisfice"- just enough to get by. To some extent, this makes sense, but as experience has shown or as common-sense dictates, satisficing may not always, if at all, mean that the "right" decision is made in the best interest of all the parties concerned.

For the most part, however, goal ambiguity is a fact of political life and this is evident in the American war on poverty. To illustrate, in his 1964 State of the Union address, President Johnson proclaimed: "This 
administration today, here and now, declares unconditional war on poverty in America". The question is, what exactly does the phrase "unconditional war" mean? As the author sees it, the phrase is ambiguous, vague, and unclear because reasonable people will differ as to the exact meaning of the phrase. From another perspective, the phrase is suspect in the sense that President Johnson — a man who had the spirit and the desire to help the "poor"-linked what was supposed to be a charitable and godly project to a war. No wonder former President Ronald Reagan said, "We fought a war on poverty and poverty won" (Edelman, 2012).

Second, the threshold "poverty line" upon which the war on poverty is fought is, as has already been noted, ambiguous, vague, arbitrary, and misleading, because it does not take into account most (if not all) of government means-tested spending on the poor. Aaron (1978) put it very well when he said, "The problems of being poor are not switched on suddenly when income falls below (the poverty line) and switched off when income rises above it".

Third, in declaring the war on poverty, Johnson said: "Our aim is not only to relieve the symptom of poverty, but to cure it and, above all, to prevent it". Surely, the author does not believe there is any American out there who does not cherish these life-saving and inspiring goals, because they are designed with good intentions - to rescue fellow Americans from economic catastrophe. In reality, however, these goals are both ambiguous and unattainable. To illustrate, it is not possible to eliminate poverty completely in any society, because the root causes of poverty and its dynamics and sophistications are beyond human comprehension and capability. This means that, American government, no matter how hard it tries, will not be able to eliminate poverty completely by throwing trillions of dollars at the poverty problem in the hope that it will go away; it will not. As previously noted, the poor will always be with us. As Hogwood and Peters (1985) noted, "The temptation in launching programs to tackle such ills as poverty... is to set as the target their complete elimination. Yet such absolute targets may be unattainable...". Similarly, Aaron (1978) said: "In the event, money was thrown at problems, especially at problems of the poor, but those problems refused to go away". That may be true, but as he will argue later, with hard work and luck-not the current American welfare system - it is possible for anybody to rise above poverty because he does not believe that poverty is a permanent curse.

\section{Unrealistic Expectations}

Unrealistic expectations have two faces. First, citizens sometimes expect too much from their government. This may be one of the reasons former President John F. Kennedy said in his January 20, 1961 inaugural address: "Ask not what your country can do for you, ask what you can do for your country" (Kennedy, 1961). In response to citizens' demands, government creates more programs. This in turn creates a never-ending vicious circle (more demands, more programs).

Second, in an attempt to appease the citizens, governments and politicians promise them more than they can ever deliver. For better or worse, this practice is a fact of political life; and all politicians play the game in order to survive. Thus, in order to sell their programs, politicians must convince the citizens that the programs will solve their problems. Not only does this practice contribute to program failure, it also reduces public confidence in the capability of government to do the right thing. Hogwood and Peters (1985) put it very well when they said: "These promises then get governments into situations which make them appear more impotent than they are, and certainly more naïve than many of the people who work in government are". Similarly, Ripley and Franklin (1986) said: "In their zeal to pass programs, supporters often claim too much, thus inflating 
expectations of what the program can accomplish. These claims foreordain program 'failure' if accomplishments are measured against exaggerated goal statements".

So, what does all this have to do with the war on poverty? As has been noted, the war on poverty was oversold by President Johnson when he launched it. To avoid repetition of what has already been said, it suffices here to say that the war on poverty was launched on the assumption that it would solve the problems created by generations of poverty overnight. That has not happened and it will probably not happen in our life time, because the root causes of poverty are too many and too complicated to be solved by any magic formula or program such as the American war on poverty. Because the war on poverty was oversold, it failed to deliver what it promised American people. In this regard, the problem is not the people who implement the anti-poverty programs, because the author does not think that government is filled with a bunch of incompetent people who do not know what they are doing. Rather, he believes that the problem rests in the fact that the war on poverty was oversold, because it promised more than it can ever deliver. The following excerpt by Kettl and Milward (1996) will make this point clear:

Too often, both citizens and policy makers dream ambitious dreams that can never be completely fulfilled. They sometimes lose faith when disappointments occur. They react to demanding more performance from government and they seek accountability through improved control, yet, they search for control in programs whose very structure defies the attempt. To a huge degree, many of the American government's most profound governance problems lie rooted in the discontinuity between the ambition and the system designed to achieve it. (Kettl \& Milward, 1996, p. 10)

\section{Implementation Problem}

As a point of departure, it is important to note that a program, no matter how well it is designed, is not self-executing. Thus, the dynamics and intricacies of implementation may create a situation of a "prophet without a prophecy" in which implementation may deviate from its original design and confound the intentions of the policy makers. For example, with regard to government programs, implementation activities usually involve all levels of government, private and non-profit organizations, interest groups, clienteles, etc. Under this complicated and complex network, the probability of "screwing-up" the implementation process and skewing the outcome or result of a program is extremely high. That said, the author believes that the following implementation problems contributed, directly or indirectly, to the failure of the war on poverty?

First, with respect to the intricacies of the war on poverty, Tanner (2012) noted that "seven different cabinet agencies and six independent agencies administer at least one anti-poverty program". Arguably, this complex design might have led to the failure of the war on poverty.

Second, as Duquette (2014) pointed out, "Instead of directing funds to state anti-poverty programs, the Johnson administration had the power and discretion to make grants directly to community organizations with minimal oversight from state or local governments or from Congress". Duquette added: "The Johnson administration promised too much relative to the resources they committed to the cause... While recent research has found that (the anti-poverty) programs were effective, they lacked the scale to reach all poor Americans". In other words, with respect to the war on poverty, Johnson did not put enough money where his mouth was.

\section{Summary}

The author now comes full circle to the big question that has driven this study: If the war on poverty was supposed to change the lives of poor Americans for the better, how come it has not been able to achieve this 
noble goal despite the trillions of dollars that have been invested in it? Put another way around, what, if any, prevents the American war on poverty from realizing its great promise? Unfortunately, as laudable as these questions sound, they cannot be answered in the affirmative. This is not a contradiction to the reasons for the failure of the war on poverty discussed earlier, because as he indicated, the reasons are only suggestions or probabilities. That said, there are at least two reasons why the questions posed above cannot be answered in the affirmative. First, the story of the American war on poverty is a typical example of Miles' Law which said: "Where you stand depends on where you sit" (Miles, 1978). Second and related to Miles' Law, it appears that the war on poverty has many enemies and friends - those who, for various reasons, are against the war and those who are in favor of it. Thus, he argues that differences in perceptions make it difficult to conclude unequivocally that the war on poverty is a failure or a success. To illustrate, those who oppose the war on poverty (e.g., left-wing policy makers) will always consider it a failure no matter what its outcomes or results are. On the other hand, those who are in favor of the war on poverty (e.g., right-wing policy makers) will always consider the war to be effective, even though the opposite is true. Under this "who is right and who is wrong" condition, it is difficult to draw any conclusive and affirmative conclusion regarding the success, failure, and impact of the war on poverty. This is not to say that the war on poverty is effective or not effective. After all, without the war on poverty, the poverty and hardship of poor Americans would have increased and this would have pushed them into destitution. Another way to put it is that poor Americans are still poor, but less poor than before the war on poverty.

To avoid the "family feud" in the war on poverty or to avoid being cut in the cross-fire between the critics of the war on poverty, on both the left and the right wings, the author suggests that we focus on the "symbolic" impact of the war on poverty rather than its "tangible" impact. The symbolic impact of a program, according to Dye (1978), is as follows:

The symbolic impact of a program (emphasis added) deals with the perceptions that individuals have of government action and their attitudes toward it. Even if government policies do not succeed in reducing dependency, or eliminating poverty, or preventing crime, and so on, this may be a rather minor objection to them if the failure of government to try to do these things would lead to the view that society is "not worth saving". Individuals... and whole societies frequently judge public policy in terms of its good intentions rather than its tangible accomplishments... For example, a government "war on poverty" may not have any significant impact on the poor, but it reassures moral men, the affluent as well as the poor, that government "cares" about poverty. (Dye, 1978, p. 315)

Quite frankly, the author agrees with Thomas Dye in his explanation of the symbolic impact of a government program. For one reason, he firmly believes that government exists to cater for the needs of its citizens - regardless of whether the needs are met or not. For example, although former President George W. Bush's War on Terror may be considered a failure and a catastrophe by most people, he made an effort to protect the American people - a test of good leadership. As Schurz (1913), one of the leading reformers of the U.S. Civil Service Reform movement of the 1880 's, put it, “...the question of whether the departments at Washington are managed well or badly is, in proportion to the whole problem, an insignificant question". In effect, Schurz was speaking on behalf of the American people; not departments and buildings in Washington. Along this line, Wilson (1989) said: "The governments of the United States (are not) designed to be efficient (and effective), but to be tolerable and malleable". The author totally agrees with Schurz and Wilson, because if efficiency and effectiveness were the only values of a democratic government, there would be no programs to serve the people. Invariably, this will render the American Constitution which begins with the words "We the 
People" and former President Abraham Lincoln's definition of democracy_-"government of the people, by the people, (and) for the people" meaningless.

The crucial point to remember is that for various reasons, including those addressed in this paper, the American war on poverty may not change the conditions of poor Americans, but merely make them feel that their government cares. Yes, President Johnson's war on poverty may be a failure and a catastrophe. But the fact that Johnson made a good-faith effort to address the poverty problem in America, he offered poor Americans hope and visions of a better world.

\section{Conclusions}

After thoroughly reviewing the literature on the American war on poverty, the author comes to the following inevitable conclusions. First and foremost, the concept behind how American government wage war on poverty is completely wrong. For example, encouraging dependency on Uncle Sam rather than self-sufficiency and self-support is totally wrong. Second, although there are good intentions behind the war on poverty, it has "boomerang effect" and "moral hazard" problems in the sense that it weakens work incentives and perpetuates dependence on Uncle Sam. Third, the war on poverty operates on the principle of "diminishing return", which simply means that the more money American government spends on the war, the less return it gets. Tanner (2012) expressed this sad and undesirable situation in four words - "more money, more poverty". This means that the solution to the poverty problem is worse than the problem itself. Having said all that, the inevitable question is: How can we make the war on poverty work better and more effectively? The answers to this question (discussed below) are based on the following fundamental humanistic, caring and moral principles and beliefs upon which the United States - a land of opportunity full of milk and honey-is founded.

First, as far as the author knows, the United States is the one and only country in the world whose constitution begins with the words "We the People". These words do not need any philosophical and legalistic explanation or interpretation because they mean what they say. Simply put, the United States Founding Fathers value human beings more than anything else. As Tocqueville noted after The Grand Convention of 1787, "The people reign in the American political world as the Deity does in the Universe. They are the cause and the aim of all things; everything comes from them and everything is absorbed by them" (Stillman, 1987).

Second, as far as the author knows, the United States is the one and only country in the world whose constitution contains the phrase "promote the general welfare". Again, this phrase, like the "We the People" phrase that precedes it, means what it says - promote the welfare of the American people. Although some constitutional scholars may quibble with this simple interpretation of the phrase "promote the general welfare", it is consistent with Tocqueville's observation. Also, the interpretation is based on the belief that the word "welfare" makes more sense when it is applied to human beings with breath, life, blood, and feelings than when it is applied to the American governmental system as some constitutional scholars and legal experts would like to interpret it.

Last, but certainly not least, as far as the author knows, the United States is the one and only country in the world that claims to be a "nation under God". Let us be realistic. Can a nation under God let God's children go hungry? Unless we are deceiving ourselves, the answer is a resounding no because doing so is a contradiction to God's will.

No doubt, the fundamental principles and beliefs discussed above pose serious challenges for the American people and government. To illustrate, if a country (America, in this case) that prefaces its 
constitution with godly, humanitarian, and caring words like "We the People" and promotes the general welfare and at the same time claims to be a nation under God "cannot help the many who are poor, it cannot save the few who are rich either (emphasis added)" (Kennedy, 1961). Kennedy is not alone in this crusade. For example, according to Harrington (1981),

In morality and in justice, every citizen should be committed to abolishing poverty (emphasis added), for it is intolerable that the richest nation in human history should allow such needless suffering. But more than that, if we solve the problem of poverty (emphasis added) we will have learned how to solve the problems of all of America.

In like manner, Saint Francis of Assisi said, "It is no use walking anywhere to preach unless our walking is our preaching" (Pierce, 2001). This means that American government must make every effort to convert its good words and promises contained in the U.S. Constitution into good deeds by helping poor Americans. Of course, American government has been doing this for years - kudos-but more is expected of it.

Yes, the war on poverty may have seriously weakened work incentives and perpetuated dependence on Uncle Sam. Yes, poor Americans may have brought poverty upon themselves. The question is, so what? No matter the negative and undesirable effects of the war on poverty, the fact remains that poor Americans are Americans - a right that cannot simply be taken away from them. As such, poor Americans should not be denied the "welfare" protection clause in the United States Constitution, because they are poor or because policy makers feel that the war on poverty is a bad and an unprofitable business. No, it is not. As Hogwood and Peters (1985) rightly pointed out, "Government expenditures should not be regarded as a public bad, but as simply government's attempt to meet the demands of citizens". To paraphrase Moe (1994),

The management of government is not like the management of General Electric or the Ritz-Carlton Hotels. Government does not have the option available to private sector companies of simply stopping the performance of some activity because it is not profitable. (Moe, 1994, p. 119)

As Tocqueville noted several years ago, American people, both poor and rich, are "the cause and the aim of all things; everything comes from them and everything is absorbed by them".

Having said all that, the author's suggestions to make the American war on poverty more effective and productive are based on the issues raised above and on the following observations. First, as the Chinese parable says, "If you give a man a fish, you feed him for one day; but if you teach him how to fish, you feed him for life", provided he is willing to fish (the author's words). Second, to imitate Tanner (2013), poor Americans are not stupid. If they are, it is because they are responding directly and affirmatively to the American welfare system which weakens work incentives and perpetuates dependence on Uncle Sam. Third, we need to go back to President Johnson's original goal when he launched the war on poverty - to give our fellow Americans a fair chance to develop their own capacities. To achieve this productive, "life-saving" goal, American government must change its attitude from babysitting and pampering "able" poor adult Americans with welfare checks and free food-because most would prefer work to welfare checks - to providing them with the tools they definitely need to develop their own capacities. Such tools include but are not limited to the following:

\section{Create More Job Opportunities for Poor Americans}

While America is often called a land of opportunity - full of milk and honey - this is not true for everybody, especially the poor. Therefore, American government should see to it that the poor get a fair share of the available jobs as a fulfillment of its equal employment opportunity policies and laws. The following 
excerpts are an excellent example of and testimony to this suggestion:

(1) The eradication of poverty cannot be accomplished through anti-poverty programmes (sic) alone but will require democratic participation and changes in economic structures in order to ensure access for all to resources, opportunities and public services, to undertake policies geared to more equitable distribution of wealth and income, to provide social protection for those who cannot support themselves... (United Nations World Summit for Social Development, 1995)

(2) ...if the ideal announced by President Johnson in 1964 is ever to be fulfilled, and poverty banished from this nation, it will take more radical departures in economic and social policy than Johnson ever imagined. (Harrington, 1981)

\section{Tighten up Work Requirements as a Condition for Receiving Welfare Benefits}

The current American welfare system stinks because it encourages unmarried teenage girls to stay home and make more babies in order to receive more welfare benefits. If welfare recipients are required to aggressively look for work and be willing to work, they will not stay home all day to make babies at the expense of the taxpayers. This policy will make the welfare recipients to become productive people while reducing welfare rolls.

\section{Create Training Programs and Counseling Centers for Poor Americans}

Arguably, the problem with most poor Americans is not necessarily lack of education, but lack of motivation and inspiration. Thus, they desperately need someone to motivate and inspire them; to preach to them life-changing words of hope that can turn their lives around; and to give them hope and visions of a better world. As is written: "Where there is no vision, the people perish..." (Prov. 29:18 KJV). While there is still hope, we do not want our fellow poor Americans to perish for lack of vision, inspiration, motivation, and encouragement.

To poor Americans, here is the author's personal advice for you. Yes, you may be living in poverty right now, but do not ever let poverty live in you or get stuck in poverty. After all, you were created to be a winner and a victor, not a loser and a victim of poverty. Therefore, the author implores you to make some efforts to rise above poverty. If you do not, you will turn the small storm in your life into a Tornado... you do not want this. In the words of former President John F. Kennedy (1961), "The world is very different now. For man, and presumably woman, (emphasis added) holds in his (or her) mortal hands the power to abolish all forms of human poverty". President Kennedy is absolutely right and the time is now for you to use that power in your hand to rise above poverty. If not now, when?

The above piece of advice is based on the author's firm belief that the poor, irrespective of sex, age, racial, and parental backgrounds need not always be with us. However, until the advice is taken to heart and acted upon, the poor will be with us until the end of time.

\section{References}

Aaron, H. J. (1978). Politics and the professors: The great society in perspective. Washington, D.C.: The Brookings Institution. Denhardt, J. V., \& Denhardt, R. B. (2007). The new public service: Serving, not steering. Armonk, NY: M.E. Sharpe.

Duquette, N. (2014). Why the war on poverty failed. Retrieved from http://www.slate.com

Dye, T. R. (1978). Understanding public policy. Englewood Cliffs, NJ: Prentice Hall, Inc.

Edelman, P. (2012). Poverty in America: Why can't we end it? Retrieved from http://www.foreconomicjustice.org/.../poverty-inamerica-why-cant-we-end-it

Forester, J. (1984). Bounded rationality and the politics of muddling through. Public Administration Review, 44(1), 23-31.

Galbraith, J. K. (1958). The affluent society. New York, NY: Houghton Mifflin Company.

Gore, A. (1993). From red tape to results: Creating a government that works better and costs less. The Report of the National Performance Review. Washington, D.C.: US Government Printing Office. 
Harrington, M. (1981). The other America: Poverty in the United States. New York, NY: Simon \& Schuster Inc.

Henry, N. (1995). Public administration and public affairs. Englewood Cliffs, NJ: Prentice Hall.

Hogwood, B. W., \& Peters, B. G. (1985). The pathology of public policy. New York, NY: Oxford University Press.

Johnson, L. B. (1964a). Annual message to the congress on the State of the Union. Retrieved from http://www.presidency. ucsb.edu/ws/?pid

Johnson, L. B. (1964b). Modern history sourcebook: President Lyndon B. Johnson: The war on poverty. Retrieved from http://legacy.fordham.edu/hals11/mod/1964johnson-warpoverty.html

Jung, C. S. (2014). Extending the theory of goal ambiguity to programs: Examining the relationship between goal ambiguity and performance. Public Administration Review, 74(2), 205-218.

Kennedy, J. F. (1961). Ask not what your country can do for you. Retrieved from http://www.ushistory.org/documents/ ask-not-htm

Kettl, D. F., \& Milward, H. B. (Eds.). (1996). The state of public management. Baltimore, MD: The Johns Hopkins University Press.

Lindblom, C. E. (1959). The science of "muddling through". Public Administration Review, 19(2), 79-88.

Milakovich, E. M., \& George, J. G. (2004). Public administration in America. Belmont, CA: Wadsworth/Thomson Learning.

Miles, R. E. (1978). The origin and meaning of Miles' law. Public Administration Review, 38(5), 399-403.

Moe, R. C. (1994). The "reinventing government" exercise: Misinterpreting the problem, misjudging the consequences. Public Administration Review, 54(2), 111-122.

Oladeji, S. I. (n.d.). Lecture note on definitions and measurement of poverty. Retrieved from http://www.oauife.edu.ng/.../ DEFINITION-AND...

Pierce, G. F. A. (2001). Spirituality at work: 10 ways to balance your life on-the-job. Chicago, IL: Loyola Press.

Rector, R. (2014). The war on poverty: 50 years of failure. Retrieved from http://www.washingtontimes.com/...rector-the-war-on...

Rector, R., \& Sheffield, R. (2014). The war on poverty after 50 years. Retrieved from http://www.heritage.org/research/ reports/2014/09/the-war-on-poverty

Ripley, R. B., \& Franklin, G. A. (1986). Policy implementation and bureaucracy. Pacific Grove, CA: Brooks/Cole Publishing Company.

Roosevelt, F. D. (1932). Franklin D. Roosevelt, xxxii president of the United States: 1933-1945. 131-address accepting the presidential nomination at the Democratic National Convention in Chicago. Retrieved from http://www.presidential. ucsb.edu/ws/?pid=75174

Rossi, P. H., \& Freeman, H. E. (1982). Evaluation: A systematic approach. Beverly Hills, CA: Sage Publications, Inc.

Schurz, C. (1913). Speeches, correspondence, and political papers of Carl Schurz, volume 6. F. Bancroft, (Ed.). New York, NY: G.P. Putnam's Sons.

Simon, H. (1947). Administrative behavior. New York: Free Press.

Sribnick, E. (2014). Communities, individuals, and the long fight against poverty. Retrieved from http://www.commondreams. org/.../communities...

Stillman, R. J. (1987). The constitutional bicentennial and the centennial of the American administrative state. Public Administration Review, 47(1), 4-8.

Tanner, M. (2012). The American welfare state: How we spend nearly $\$ 1$ trillion a year fighting poverty-And fail. Retrieved from http://object.cato.org/pubs/pas/PA694.pdf

Tanner, M. D. (2013). Why get off welfare? Retrieved from http://www.cato.org/publications/commentary/why-get-welfare

The New Deal \& 3R'S-Relief, Recovery, Reform. (n.d.). Retrieved from http://Karolandjordan.weebly.com/the-newdeal...three-rs.html

The New Deal. (n.d.). Retrieved from http://rooseveltinstitute.org/policy-and.../new-deal

Thompson, J. D. (1967). Organizations in action. New York: McGraw-Hill.

United Nations World Summit for Social Development, Copenhagen. (1995). Retrieved from http://www.un.org/esa/socdev/ wssd/text-version

Vedung, E. (1997). Public policy and program evaluation. New Jersey: Transaction Publishers.

Wildavsky, A. (1979). The politics of the budgetary process. Boston, MA: Little, Brown and Company.

Wilson, J. Q. (1989). Bureaucracy: What government agencies do and why they do it. New York, NY: Basic Books, Inc.

Wilson, W. (1941). The study of administration. Political Science Quarterly, 56(4), 481-506. 